\title{
A importância da qualidade da água reagente no laboratório clínico
}

Primeira submissão em 19/05/11 Última submissão em 19/05/11 Aceito para publicação em 20/05/11 Publicado em 20/06/11

\section{The importance of water quality in clinical laboratory reagent}

Maria Elizabete Mendes'; Carla Costa Fagundes²; Cláudio Campos do Porto ${ }^{3}$; Laiz Cameirão Bento ${ }^{4}$; Thiago Guarato Rodrigues Costa ${ }^{5}$; Ricardo Alexandre dos Santos ${ }^{6}$; Nairo Massakazu Sumita ${ }^{7}$

\begin{abstract}
unitermos
Água reagente

Tecnologias de purificação

Interferentes

Métodos de purificação de água

\section{resumo}

A água é um reagente utilizado na maioria dos testes laboratoriais e por isso deve seguir um padrão de controle de qualidade rigoroso. O fornecimento urbano de água apresenta moléculas orgânicas, íons inorgânicos, partículas, coloides, gases, bactérias e seus produtos, que podem alterar os resultados dos exames laboratoriais e causar eventuais erros e falhas mecânicas em equipamentos analíticos. Para remover essas impurezas, é necessário recorrer a uma combinação de tecnologias de purificação. Há várias organizações que especificam normas sobre a água reagente, a fim de minimizar sua interferência nos ensaios laboratoriais. A maioria dos laboratórios utiliza as normas estabelecidas pelo Clinical and Laboratory Standards Institute (CLSI) que classifica a água em: clinical laboratory reagent water (CLRW), special reagent water (SRW) e instrumental feed water (IFW). O monitoramento da qualidade é realizado pela determinação de resistividade, condutividade, carbono orgânico total (TOC), controle microbiológico e endotoxinas. Os parâmetros são avaliados de acordo com a periodicidade estabelecida pela norma utilizada. Neste artigo, discutem-se a importância da água utilizada nos procedimentos laboratoriais, o controle da qualidade e as interferências nos ensaios laboratoriais.
\end{abstract}

\section{abstract}

Water is a reagent used in most laboratory tests and, therefore, must follow stringent quality control standards. The urban water supply has organic molecules, inorganic ions, particles, colloids, gases, bacteria and their products, which may alter laboratory test results and cause occasional errors and mechanical failures in diagnostic equipment. To remove these impurities, it is necessary to use a combination of purification technologies. There are several organizations that specify reagent water standards to minimize its interference in laboratory assays. Most laboratories set standards established by the Clinical and Laboratory Standards Institute (CLSI), which classifies the type of water as follows: clinical laboratory reagent water (CLRW), special reagent water (SRW) and instrumental feed water (IFW). The quality monitoring is performed by means of assessing the resistivity, conductivity, total organic carbon (TOC), microbial control and endotoxins. The parameters are evaluated in accordance with the frequency determined by the standard used. In this article we discuss the importance of water employed in laboratory procedures, its quality control and its interference in laboratory assays. key words

Reagent water reagent

Purification technologies

Interfering

Water purification methods

1. Doutora em Medicina (Patologia); médica patologista clínica; chefe da Seção Técnica de Bioquímica de Sangue da Divisão de Laboratório Central do Hospital das Clínicas da Faculdade de Medicina da Universidade de São Paulo (DLC/HC-FMUSP) (LIM-03 da Patologia Clínica); coordenadora do Núcleo de Qualidade e Sustentabilidade da DLC/HC-FMUSP.

2. Biomédica (aprimoramento em Patologia Clínica no HC/FMUSP).

3. Farmacêutico bioquímico; farmacêutico do Serviço de Bioquímica Clínica da DLC/HC-FMUSP.

4. Biomédica (aprimoramento em Patologia Clínica no HC/FMUSP).

5. Biomédico (aprimoramento em Patologia Clínica no HC/FMUSP).

6. Farmacêutico bioquímico; farmacêutico do Serviço de Bioquímica Clínica da DLC/HC-FMUSP.

7. Doutor em Medicina; professor da disciplina de Patologia Clínica da FMUSP; médico patologista clínico; diretor do Serviço de Bioquímica Clínica da DLC/HC-FMUSP (LIM-03 da Patologia Clínica); assessor médico em Bioquímica Clínica do Fleury Medicina e Saúde. 


\section{Introdução}

As decisões clínicas apoiam-se não somente no resultado do teste, mas na conjugação de sua história clínica com os sintomas. Os resultados laboratoriais de qualidade dependem da confiabilidade da instrumentação e da qualidade da água. Fatores analíticos precisam ser controlados e otimizados para reduzir o número de possíveis falhas que possam se refletir nos resultados ${ }^{(6)}$.

A água é um elemento essencial que contribui para o desenvolvimento e a qualidade do laboratório. É o reagente mais utilizado na prática laboratorial ${ }^{(6)}$. Em função da natureza química de sua molécula, as propriedades físicas e químicas da água diferem muito das de qualquer outra substância. Uma característica da água, no estado líquido, é a sua capacidade de dissolver substâncias polares ou iônicas para formar soluções aquosas. Ela tem forte poder de dissociação e, como consequência, o material dissolvido aumenta bastante a condutividade da água. Devido à sua capacidade térmica ser elevada $\left(1 \mathrm{cal} /{ }^{\circ} \mathrm{C}\right)$, ela é capaz de adquirir ou perder muito mais calor que outras substâncias comuns, quando submetida à mesma temperatura ${ }^{(1)}$.

No laboratório, decorrem de suas propriedades as diversas aplicações: reconstituição de reagentes, diluições, soluções brancas ou padrões, preparação de soluções de enxágue e de tampões, confecção de meios de cultura, alimentação de analisadores automatizados, lavagem, sanitização e recuperação de utensílios. Portanto, esse fator analítico precisa ser controlado e otimizado para reduzir erros potenciais e garantir a qualidade dos resultados $(2,6)$.

Um dos principais problemas que afetam as atividades laboratoriais é a facilidade de contaminação da água. Há cinco tipos de contaminantes: material particulado e coloide, substâncias inorgânicas, compostos orgânicos dissolvidos, microrganismos com seus subprodutos (pirogênios) e gases ${ }^{(3,4)}$.

As águas de abastecimento urbano que alimentam os laboratórios contêm contaminantes como íons inorgânicos, moléculas orgânicas, partículas, coloides, gases, bactérias e seus produtos. Os íons inorgânicos podem afetar reações bioquímicas. As bactérias também podem interferir nas análises, seja diretamente ou pela ação de seus produtos, como os pirogênios, a atividade das nucleases e da fosfatase alcalina $^{(3,4)}$.

Para atender ao desenvolvimento de novas tecnologias, a ampliação da sensibilidade dos testes em medicina laboratorial, várias entidades em nível internacional têm estabelecido parâ- metros de qualidade para as aplicações da água reagente, a fim de minimizar suas interferências nos ensaios utilizados ${ }^{(5)}$. Entre elas, estão Agência Nacional de Vigilância Sanitária (ANVISA), American Society for Testing and Materials (ASTM), Standard Methods for Analysis of Water and Wastewaters, United States Pharmacopeia (USP) ${ }^{(5,7-9)}$, American Chemical Society (ACS), British Standards Institute (BSI), International Organization for Standardization (ISO) $)^{(9)}$, College of American Pathologists $(\mathrm{CAP})^{(10)}$, Clinical and Laboratory Standards Institute $(\mathrm{CLSI})^{(6)} \mathrm{e}$ Organização Mundial da Saúde (OMS) ${ }^{(10)}$. Essas especificações, envolvendo tipos, métodos de obtenção e controles necessários para a utilização correta, auxiliam as equipes que atuam nos laboratórios(11).

A Resolução da Diretoria Colegiada (RDC) 302:2005, da ANVISA, preconiza que o laboratório clínico, em sua fase analítica, deve definir o grau de pureza da água reagente utilizada em suas análises, a forma de obtenção e o controle da qualidade ${ }^{(11)}$.

Os padrões estabelecidos pelo CLSI são os mais comumente empregados em nosso país. O documento C3-A4 - Preparation and testing of reagent water in the clinical laboratory - define os parâmetros utilizados para cada tipo de água e, de acordo com a necessidade do ensaio, um desses tipos é escolhido. Assim, as águas foram classificadas pelo CLSI em: clinical laboratory reagent water (CLRW), special reagent water (SRW) e instrumental feed water (IFW) ${ }^{(8)}$.

As especificações do $C L S{ }^{(10)}$ em relação à contagem de unidades formadoras de colônias bacterianas (UFCs/ml) são similares para os tipos CLRW e SRW, isto é, devem ser inferiores a 10 para ambas. Quanto ao material particulado, para ambas, o filtro no final da purificação deve remover partículas com diâmetro superior a 0,22 $\mu \mathrm{m}$. Para o carbono orgânico total, os níveis aceitos devem ser inferiores a $500 \mathrm{~g} / \mathrm{g}$ na CLRW e inferiores a $50 \mathrm{ng} / \mathrm{g}$ na SRW.

O CLSI no documento C3-A4 define como classificações adicionais:

- água para autoclave e lavagem - a água deve ser purificada e conter baixos níveis de compostos orgânicos, inorgânicos e material particulado, que poderiam contaminar soluções e meios de cultura no processo de autoclavagem;

- água fornecida pelo fabricante do método - como diluente ou como reagente, deve ser empregada apenas com o conjunto diagnóstico e em nenhuma outra aplicação. Esse tipo de água não substitui as água dos tipos CLRW ou SRW; 
- água purificada fornecida envasada comercialmente - o usuário deve tomar cuidado com a degradação da água quando estocada e deve validar os parâmetros da CLRW ao longo do tempo de utilização dessa água. Cada novo lote de água envasada deve ser validado antes de seu uso.

A CLRW substitui a antiga classificação da água em tipos I e ll e é utilizada no laboratório de análises clínicas em diversas funções, como reconstituição de reagentes, padrões, calibradores e brancos de reações, lavagem de cubetas, probes e outros instrumentos. Essa água é isenta de materiais orgânicos e inorgânicos, partículas e coloides, além de bactérias e seus subprodutos ${ }^{(5,6)}$. Já a SRW é a categoria livre de nucleases (DNAses e RNAses), que é a recomendada em técnicas moleculares ${ }^{(5,6)}$. Há também a IFW, que é usada para banhos aquosos, enxágues internos de maquinário, diluições e outras funções utilizadas nos analisadores automatizados ${ }^{(5,6)}$.

Vale ressaltar que a água reagente não deve ser estocada; ela deve ser usada no momento em que é produzida, devido à contaminação por gases do ambiente e crescimento microbiano(6,12).

Como tendências atuais no monitoramento, propostas pelo CLSI, observam-se: detecção da deterioração dos componentes do sistema de purificação da água, garantia que as especificações estão sendo cumpridas continuamente e registros mínimos requeridos estão sendo efetuados, verificação diária da resistividade, contagem de UFCs mensalmente, medida do total de compostos orgânicos
(TOC) anualmente. A deterioração de um único parâmetro pode indicar a necessidade de manutenção. A expansão dos controles baseia-se na aplicação da água reagente $\mathrm{e}$ na avaliação dos riscos ${ }^{(5,6)}$.

\section{Tecnologias de purificação}

Para se tornar adequada para a utilização no laboratório, a água deve passar por purificação para a eliminação dos contaminantes dissolvidos nela, tornando-se água reagente. O processo de purificação não é específico e pode ser decorrente de uma combinação de métodos para que atenda às especificações internacionais de qualidade ${ }^{(2,6,12-14)}$.

Existem vários métodos para remoção de impurezas, por isso é necessário recorrer a uma combinação de tecnologias, associando suas vantagens (Tabela), a fim de se obter uma água de alta qualidade.

Algumas medidas anteriores e posteriores ao processo de purificação da água podem ser necessárias para melhorar a eficiência do processo de purificação, como a manutenção preventiva e a limpeza das caixas-d'água e a instalação de filtros prévios ao sistema automatizado de purificação. $\mathrm{O}$ sucesso na produção de purificação da água deve-se aos equipamentos utilizados e à sua manutenção adequada ${ }^{(6,15)}$.

Os processos de purificação são:

- filtração - processo de separação de partículas contaminantes presentes na água por meio da utilização de um material poroso, como filtros de carvão ativado ou de celulose $(5,6,13,16,17)$;

\section{Tabela Vantagens e desvantagens dos métodos de purificação}

\begin{tabular}{|c|c|c|}
\hline Método & Vantagens & Desvantagens \\
\hline Filtração & $\begin{array}{l}\text { Remoção de cloro, partículas e matéria } \\
\text { orgânica }\end{array}$ & Produto sem eliminação de íons e bactérias \\
\hline Destilação & $\begin{array}{l}\text { Remove grande porcentagem de todos os } \\
\text { tipos de contaminantes }\end{array}$ & Alto custo e consumo de energia \\
\hline Ultravioleta & Baixo uso de energia & $\begin{array}{l}\text { Danifica o mecanismo de replicação, sem } \\
\text { remoção dos microrganismos }\end{array}$ \\
\hline Deionização & $\begin{array}{l}\text { Eficiência na substituição dos compostos } \\
\text { inorgânicos }\end{array}$ & Saturação rápida das resinas de troca iônica \\
\hline Eletrodeionização & Regeneração das resinas por corrente elétrica & Não remoção de partículas e matéria orgânica \\
\hline Micro/ultrafiltração & Filtração esterilizante & $\begin{array}{l}\text { Morte dos microrganismos retidos por trás } \\
\text { do filtro }\end{array}$ \\
\hline Osmose reversa & $\begin{array}{l}\text { Remove grande porcentagem de todos os } \\
\text { tipos de contaminantes }\end{array}$ & $\begin{array}{l}\text { Membranas sujeitas a incrustações e obstruções } \\
\text { a longo prazo }\end{array}$ \\
\hline
\end{tabular}


- destilação - é usada para separar misturas homogêneas do tipo sólido-líquido, nas quais os componentes têm pontos de ebulição diferentes. O vapor da água aquecida é condensado, coletado e armazenado, removendo grande parte dos contaminantes ${ }^{(6,14,17)}$;

- desinfecção por sistema ultravioleta (UV) - a água circula no reator de esterilização. Em contato com a luz, os microrganismos são inativados pela luz UV (na faixa de 250 a $270 \mathrm{~nm}$ ), resultado do dano fotoquímico ao ácido nucleico. A localização da lâmpada deve ser anterior à troca iônica ${ }^{(6,14,17)}$;

- deionização - é utilizada para remoção de substâncias inorgânicas, empregando-se colunas com resinas carregadas eletricamente, que permitem a troca seletiva de íons por compostos inorgânicos dissolvidos na água( ${ }^{(5,6,17,18)}$;

- eletrodeionização - é um processo contínuo, em que a água passa em canais, migrando para o canal de eletrodo, seguindo através de membranas permeáveis a ânions e cátions (canais de purificação) e, por fim, pelo canal de concentração. O campo elétrico criado faz que os íons removidos transitem por canais em que ficam concentrados, enquanto o produto transita por outro canal e é estocado. Para evitar a precipitação de carbonato de cálcio ou magnésio, existem partículas de carvão ativado entre as resinas de troca iônica que são continuamente regeneradas pela corrente elétrica ${ }^{(5,6,15-17)}$;

- microfiltração e ultrafiltração - a membrana, que é colocada na saída do sistema de purificação, não permite que quaisquer partículas acima de $0,22 \mu \mathrm{m}$ a atravessem, promovendo uma filtração esterilizante, como é o caso da microfiltração. Mais recentemente, a ultrafiltração foi proposta como uma forma de eliminar outros contaminantes não eliminados pela microfiltração, pois os poros do filtro são menores, variando de 25 a $3 \mathrm{kDa}^{(5,6,13,17) \text {; }}$

- osmose reversa - é o processo de passagem de água através de uma membrana semipermeável em um sistema de alta pressão, que força sua passagem pela membrana, retendo partículas, compostos orgânicos e bactérias ${ }^{(6,17,18)}$.

\section{Controle de qualidade da água reagente}

A água reagente deve obedecer a um padrão de controle de qualidade rigoroso. O monitoramento da qualidade está explicitado a seguir.
- Determinação de resistividade e condutividade: são úteis para mensurar a quantidade de contaminantes iônicos presentes na água, porque determinam indiretamente os sólidos totais dissolvidos. As medidas da resistividade e a condutividade de uma amostra de água reagente devem ser feitas diariamente conforme descrito nas normas $\mathrm{CLSI}^{(6,15)}$.

- Determinação de TOC: o carbono total (CT) é definido pela quantidade de gás carbônico $\left(\mathrm{CO}_{2}\right)$ produzido, quando uma amostra é oxidada por completo, e inclui a matéria orgânica dissolvida e o carbono inorgânico $(\mathrm{Cl})$. O aumento do TOC inativa reagentes por ação enzimática, promovendo bloqueios dos filtros e restrição do fluxo e proporcionando paradas para a manutenção. A análise do TOC deve ser realizada mensalmente para garantir a ausência de moléculas orgânicas ${ }^{(4,6,19)}$.

- Controle microbiológico: a água de alimentação pode formar biofilmes, que interferem nos resultados de exames laboratoriais e degradam equipamentos pela biocorrosão. O biofilme é fonte de endotoxinas e polissacarídeos, gerando a contaminação e a perda da pressão da água. São realizados por meio da técnica de contagem de bactérias heterotróficas (THPC), em que o valor obtido é uma aproximação do número de microrganismos viáveis presente no sistema de purificação. As metodologias utilizadas são as técnicas de espalhamento em placa, de membrana filtrante e por microscopia de epifluorescência. O controle microbiológico deve ser feito semanalmente ${ }^{(5,6,12,20)}$.

- Endotoxinas: constituem o maior componente lipídico da membrana externa de bactérias Gram-negativas, que as liberam em seu meio circundante durante sua multiplicação ou quando morrem. As endotoxinas adsorvem-se de modo variado à maioria das superfícies, incluindo o carvão ativado e as resinas. A detecção e/ou a quantificação dos níveis de endotoxinas pode ser feita por teste do coágulo, turbidimetria ou técnica cromogênica ${ }^{(6,21-23)}$.

\section{Discussão}

No laboratório clínico, as análises são realizadas com cada vez menor volume de amostras e isso exige uma pureza cada vez maior dos reagentes, inclusive a água ${ }^{(24)}$.

A IFW é adequada para a alimentação direta de analisadores automatizados, pois pode ter especificações de 
diversos parâmetros, de acordo com o fabricante, para que tenha melhor funcionamento com menor número de interferentes. Analisadores automatizados podem utilizar CLRW desde que seja especificado pelo fabricante ${ }^{(12,15)}$.

A análise de cálcio por método colorimétrico consiste na reação do cálcio livre presente na amostra com o arsenazo, originando um complexo medido espectrofotometricamente. A concentração de moléculas orgânicas presentes na água deve ser baixa para que não se liguem ao cálcio, reduzindo, assim, a concentração real da amostra. Da mesma forma, a alta contagem de bactérias eleva o nível de proteínas ligantes do cálcio, resultando em uma diminuição de seu valor real(25).

Um sistema de purificação em que não se utiliza carvão ativado como dispositivo de pré-filtragem pode apresentar quantidade considerável de cloro residual vindo do abastecimento externo. Esse cloro residual pode levar a uma interferência de até $25 \%$ nas dosagens de cloretos e também pode interferir nos testes bacteriológicos e de enzimas ${ }^{25,26)}$.

A dosagem de sódio $(\mathrm{Na})$ e potássio $(\mathrm{K})$ pode apresentar resultados alterados se a água utilizada na diluição obtiver $1 \mathrm{mg} / \mathrm{l}$ desses analitos. Na dosagem de Na pode ocorrer um erro de 3,2\% em uma concentração de $136 \mathrm{mEq} / \mathrm{l}$; na de K, esse erro pode ser de $50 \%$ em uma concentração de $5 \mathrm{mEq} / \mathrm{L}^{(25)}$.

Nos imunoensaios, a presença de enzimas liberadas por bactérias, íons e moléculas orgânicas pode trazer interferências; por exemplo, quando houver a medida da atividade enzimática da fosfatase alcalina na amostra biológica. Algumas bactérias, como a Citrobacter sp. , secretam fosfatase alcalina e esta pode gerar reação cruzada nesse tipo de ensaio(15, 27).

A maior parte dos sistemas de água utiliza filtro de porosidade $0,22 \mu \mathrm{m}$ como parte do processo de filtração final. Estes removem partículas e bactérias maiores, no entanto, elas se decompõem por trás do filtro e a fosfatase alcalina é liberada juntamente com a água. Métodos de ultrafiltração podem ser usados eficientemente para remover bactérias menores e seus subprodutos (24).

Estudos realizados mostraram que a ultrafiltração com filtro de $13 \mathrm{kDa}$ fornece água livre de fosfatase alcalina. Tecnologias de purificação mais modernas incluem filtragem geral para reduzir a carga de partículas de entrada e osmose reversa para diminuir carga de íons, orgânicos, coloides e partículas ${ }^{(24)}$. Além disso, íons como magnésio (Mg) e zinco (Zn) são cofatores da fosfatase alcalina, enquanto o cádmio (Cd) e o fósforo (P) são inibidores da atividade dessa enzima, ressaltando a importância da água livre de íons ${ }^{(15)}$.
Já as moléculas orgânicas em alta concentração, como ácidos carboxílicos, podem se ligar aos sítios ativos da enzima e formar complexos com o cofator de metal, alterando a afinidade entre $o$ antígeno e o anticorpo ${ }^{(10,24)}$.

Os imunoensaios automatizados estão sendo muito utilizados. Neles, o volume de amostra usado é menor, o que exige maior qualidade da água para reduzir o número de falhas no teste. Calibradores incorretos, branco alto e valores de pacientes tendendo a positividade evidenciam um ensaio de má qualidade, o que pode ser ocasionado pela água contaminada ${ }^{(21)}$.

Nos testes de diagnósticos in vitro (IVD), a água é utilizada no preparo dos reagentes, mas também na realização dos ensaios, interferindo nos resultados e, consequentemente, nas decisões médicas ${ }^{(21)}$.

Nos testes de biologia molecular, as endotoxinas e proteínas como RNAses, DNAses e proteases precisam ser retiradas da água, pois essas enzimas catalisam a hidrólise de moléculas de RNA e DNA, tornando-as instáveis. A ultrafiltração é o melhor método de remoção de RNAses e endotoxinas $(10,28)$.

A reação em cadeia da polimerase (PCR) e a transcriptase reversa (RT-PCR) não podem ser contaminadas por bactérias, seus produtos, moléculas orgânicas e íons. Diversas bactérias liberam enzimas e íons que imitam o comportamento de enzimas usadas no método. Alguns íons agem como cofatores de enzimas, enquanto outros atuam como inibidores ${ }^{(10,21)}$. Os íons, como fosfato e muitos outros bivalentes, também têm capacidade de se ligar ao DNA e ao RNA das amostras, interferindo nas análises proteicas ${ }^{(8)}$.

É fundamental fazer a manutenção correta dos equipamentos responsáveis pela purificação da água, minimizando-se a contaminação microbiana ${ }^{(18)}$.

Ensaios utilizando microarrays também são afetados pela qualidade da água. A presença de compostos orgânicos e íons pode afetar as etapas de hibridização, lavagem, detecção de fluorescência e análise correta dos resultados ${ }^{(10)}$.

A cromatografia líquida de alto desempenho (HPLC) e a espectrometria de massa acoplada à cromatografia líquida (LC-MS) têm como exigência principal que a água apresente baixos níveis de moléculas orgânicas, pois estas são prejudiciais às colunas. Isso ocasiona redução da vida útil, com perda de resolução, aumentando o ruído de fundo e a interferência nos métodos de detecção (picos fantasmas). Altas concentrações de matéria orgânica também podem modificar a tensão superficial da água ou interferir em testes espectroscópicos que envolvem absorbância por UV ${ }^{(3,8,24)}$. 
A medição espectrofotométrica por sensores ópticos pode ser interferida na presença de pequenas bolhas formadas por gases como o nitrogênio. Essas bolhas podem ser removidas por meio da utilização de um cartucho de fibra de desgaseificação(24).

Na preparação de meios de cultura deve-se utilizar água produzida por osmose reversa, por ser livre de substâncias bactericidas. Os parâmetros que devem ser verificados nessa água incluem condutividade, $\mathrm{pH}$ e presença de grande concentração de íons de cobre, visto que estes inibem o crescimento bacteriano ${ }^{(29)}$.

Após ter demonstrado a interferência dos contaminantes nos diversos testes, afirma-se o quanto a água é fundamental para a realização dos procedimentos laboratoriais. Com isso, todos os parâmetros precisam ser monitorados, pois a qualidade da água entregue ao analisador é tão importante quanto a de qualquer outro reagente.

\section{Conclusão}

A implantação das boas práticas no laboratório clínico é essencial em função das exigências normativas que requerem um controle de qualidade rigoroso. Tal sistemática vem sendo aplicada em todos os processos, particularmente no que diz respeito à qualidade da água reagente, antes negligenciada.

A água reagente apresenta especificações internacionais de qualidade, pois as novas tecnologias de ensaio são refratárias à água reagente de baixa qualidade. $O$ tipo de água e a respectiva especificação devem estar de acordo com os requisitos analíticos da metodologia em uso. $\mathrm{O}$ tratamento da água deve ser rigorosamente monitorado para que não ocorram acúmulo de biofilme e contaminação orgânica e inorgânica, os quais podem levar à alteração dos resultados de exames. Assim, os cuidados na preparação e no manuseio da água auxiliam na minimização de possíveis erros analíticos, aumentando a confiabilidade dos resultados.

\section{Referências}

1. ASSOCIATION for the Advancement of Medical Instrumentation, American National Standards, Inc. AAMI standard and recommended practices. Arlington, Dialysis, v. 3, 1993.

2. ASTM - Standard Specificacion for Reagents Water. ASTM document D 1193-91. 1991.

3. BASQUES, F. W. A. A água como reagente. Labtest, 2010. Disponível em: <http://www.labtest.com.br/publicacoes/ publicacoeslabtest>. Acesso em: 7 maio 2011.

4. BASU, S.; PAL, A.; DESAI, P. K. Quality control of culture media in a microbiology laboratory. Indian $\mathrm{J}$ Med Microbiol, 2005. Disponível em: <http://www.ijmm. org /text.asp?2005/23/3/ 159/16586>. Acesso em: 18 jan. 2011.

5. BÔLE, J.; MABIC, S. Utilizing ultrafiltration to remove alkaline phosphatase from clinical analyzer water. Clin Chem Lab Med, v. 44, n. 5, p. 603-8, 2006.

6. BRASIL. Ministério da Saúde. Agência Nacional de Vigilância Sanitária (ANVISA). Dispõe sobre regulamentação técnica para funcionamento de laboratórios clínicos. Resolução da Diretoria Colegiada, RDC no 302, 2005.

7. BURLIN, C. L.; ALBERTÃO, F. Qualidade no laboratório. Rev Meio Filtrante, ed. 26, ano VI, 2007. Disponível em: $<\mathrm{http}: / / w w w . m e i o f i l t r a n t e . c o m . b r / m a t e r i a s \_v e r . a s p ? a c$ tion $=$ detalhe\&id $=296 \&$ revista $=n 26>$. Acesso em: 12 jan. 2011.

8. CARAWAY, W. T. Chlorine in distilled water as a source of laboratory error. Clin Chem, v. 4, n. 6, 1958.

9. CleMENTINO, M. R. A.; NETO, P. J. R.; ALENCAR, J. R. B. Carbono orgânico total: metodologia analítica e aplicações para indústria farmacêutica. Rev Bras Farm, v. 89, n. 1, p. 74-80, 2008.
10. CLSI - Clinical and Laboratory Standards Institute. Preparation and testing of reagent water in the clinical laboratory. Approved guideline. $4^{\text {th }} \mathrm{ed}$. CLSI document C3-A4 [ISBN 1-56238-610-7], 2006.

11. COMISSION on Laboratory Inspection and Acreditation. Reagent water specification. Chicago, College of American Pathologists, 1985.

12. LABORATORY Water Purification. Labconco Corporation. Disponível em: <http://www.expotechusa.com/catalogs/ labconco/pdf/guide_water.pdf>. Acesso em: 7 maio 2011.

13. LONG, J.; MABIC, S. The impact of water quality on IVD testing. In vitro Diagnostic Technology, 2009. Disponível em: <http://www.ivdtechnology.com/article/impactwater-quality-ivd-testing>. Acesso em: 12 jan. 2011.

14. LONG, J.; MABIC, S. Water quality in patient testing. Clinical Lab Prod, 2007. Disponível em: <http://www. clpmag.com/issues/articles/2007-04_08.asp>. Acesso em: 19 jan. 2011.

15. LOPES, H. J. J. Garantia e controle da qualidade no laboratório clínico, 2003. Disponível em: <http://www. goldanalisa.com.br/publicacoes/Garantia_e_Controle_ da_Qualidade_no_Laboratorio_Clinico.pdf>. Acesso em: 10 jan. 2011.

16. MABIC, S. Maintaining water quality in clinical chemistry. Advance for Medical Laboratory Professionals, v. 15, n. 8, 2007.

17. MABIC, S. Water for clinical chemistry. Application note, 2006.

18. MABIC, S.; KANO, I. Impact of purified water quality on molecular biology experiments. Clin Chem Lab Med, v. 41, n. 4, p. 486-91, 2003.

19. McFETERS, G. A. et al. Distribution of bacteria within operating laboratory water purification systems. Applied 
and Environmental Microbiology, v. 89, n. 5, p. 1410-5, 1993.

20. MILLIPORE Corporation. Pure water for biomedical laboratories. Water Purification, 2009.

21. MILLIPORE Corporation. Water purification. Reference guide, 2008.

22. PNCQ - Programa Nacional de Controle de Qualidade: Educação Continuada. Água reagente no laboratório clínico. Disponível em: <http://www.pncq.org.br/ participantes/atualizacao_baixo_001.asp>. Acesso em: 7 maio 2011.

23. PROGRAMA DE ACREDITAÇÃO DE LABORATÓRIO CLÍNICO. Norma PALC, 2010. Disponível em: <http:// www.sbpc.org.br/upload/conteudo/320101108101701. pdf>. Acesso em: 13 jan. 2011.
24. PURIFICATION Systems. Applied and Environmental Microbiology, v. 59, n.5, p. 1410-5, 1993.

25. SANTOS, D. F. F. Tecnologia de tratamento de água. 3. ed. São Paulo: Nobel, 1989.

26. SILVA, C. H. P. M. et al. Caracterização dos biofilmes formados em filtros de carvão ativado de sistemas de purificação de água em laboratórios clínicos. Rev Bras de Análises Clínicas, v. 38, n. 4, p. 243-53, 2006.

27. STEWART, B. M. The production of high- purity water in the clinical laboratory. CE Update Water III. Lab Medicine, v. 31, n. 11, p.605-11, 2000.

28. WHITEHEAD, P. Laboratory monitoring of total organic carbon in ultrapure water. Application Note. American Laboratory, 2003.
Endereço para correspondência

Maria Elizabete Mendes

Divisão de Laboratório Central do HC-FMUSP Núcleo da Qualidade

Av. Dr. Enéas de Carvalho Aguiar, 155 - Prédio dos

Ambulatórios $-2^{\circ}$ andar - Bloco 9

CEP: 05403-010 - São Paulo-SP

e-mail: ccq.dlc@hcnet.usp.br 